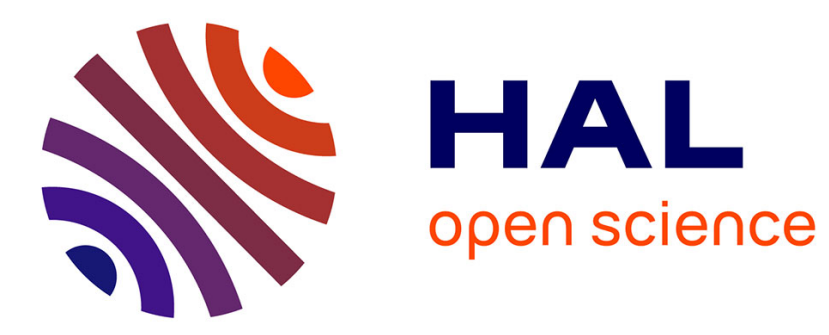

\title{
Geographic intra-specific variation in social organization is driven by population density
}

\author{
Carsten Schradin, Florian Drouard, Gildas Lemonnier, Richard Askew,
} Charlotte Anaïs Olivier, Neville Pillay

\section{- To cite this version:}

Carsten Schradin, Florian Drouard, Gildas Lemonnier, Richard Askew, Charlotte Anaïs Olivier, et al.. Geographic intra-specific variation in social organization is driven by population density. Behavioral Ecology and Sociobiology, 2020, 74 (9), 10.1007/s00265-020-02896-z . hal-02930773

\section{HAL Id: hal-02930773 \\ https://hal.science/hal-02930773}

Submitted on 10 Sep 2020

HAL is a multi-disciplinary open access archive for the deposit and dissemination of scientific research documents, whether they are published or not. The documents may come from teaching and research institutions in France or abroad, or from public or private research centers.
L'archive ouverte pluridisciplinaire HAL, est destinée au dépôt et à la diffusion de documents scientifiques de niveau recherche, publiés ou non, émanant des établissements d'enseignement et de recherche français ou étrangers, des laboratoires publics ou privés. 
1 Geographic intra-specific variation in social organization is driven by population density

2

3 Published as

4 Schradin, C., Drouard, F., Lemonnier, G. et al. Geographic intra-specific variation in social

5 organization is driven by population density. Behav Ecol Sociobiol 74, 113 (2020).

https://doi.org/10.1007/s00265-020-02896-Z

7

8 Carsten Schradin ${ }^{1,2, *}$, Florian Drouard ${ }^{2}$, Gildas Lemonnier ${ }^{1,2}$, Richard Askew ${ }^{2}$, Charlotte-

9 Anaïs Olivier ${ }^{1}$, Neville Pillay ${ }^{2}$

10

${ }^{1}$ CNRS, UMR7178, 67087 Strasbourg, France

$12{ }^{2}$ School of Animal, Plant and Environmental Sciences, University of the Witwatersrand, 13 South Africa.

14

* Corresponding author carsten.schradin@,iphc.cnrs.fr, + 33 (0)3 88106919

16

\section{Acknowledgments}

18 We thank P. Vuarin., C. Rochais, L. Kotze and several field assistants for help in collecting 19 the data. The comments of A. Ophir and of three anonymous referees significantly improved 20 the manuscript. We are grateful to Goegap Nature Reserve. This study was made possible by 21 the administrative and technical support of the Succulent Karoo Research Station, (registered 22 South African NPO 122-134). 


\section{Abstract}

Social flexibility enables individuals to switch between group- and solitary-living, and is suggested to be an adaptation to varying environments. Several previous studies on different species compared two populations and hypothesized that observed differences in social organization were due to differences in population density, but lacked the necessary sample size to test this prediction. In a previous 8-year long-term study, we showed that one population of African striped mice (Rhabdomys pumilio) displayed temporal social flexibility, living solitarily in years when population density was low, but in groups in years when population density was high. Building on this temporal variation, we now tested whether geographic variation reveals the same pattern. We studied 6 populations in discrete geographical locations simultaneously, predicting more solitary living in populations with lower population density. Population density correlated significantly with the percentage of striped mice living in groups whereas other (environmental) factors were not significant. Moreover, some individuals dispersed over unoccupied habitats between these populations, switching from group- to solitary living. Geographic variation in population density could make social flexibility adaptive, because it allows individuals to respond quickly to the prevailing conditions they experience post dispersal. Our results suggest that geographic variation drives the evolution of social flexibility in our metapopulation of striped mice, causing intra-specific variation in its social organization, which might also be important in other species, especially in species with a fast life history.

\section{Significance statement}

Populations of the same species can differ in their social organization. It has often been assumed that this is due to differences in population density. We studied 6 populations of the African striped mice, showing that more mice were solitary living when population density was low. Thus, we demonstrated that population differences in social organization were due to differences in population density.

Key words group living; intraspecific variation; social evolution; social system; social organization; solitary living 


\section{Introduction}

Animal species show an interesting variety of social systems, such as solitary living, groupliving and even eusociality. Social systems consist of several subsystems that should be studied independently. These include social organization (composition of groups), social structure (social interactions), mating system, and care system (who takes care of dependent offspring) (Kappeler and Schaik 2002; Kappeler et al. 2019). Most of the available data concern social organization, since group composition is easy to measure. Social organization can be solitary living, pair-living or living in groups of different composition (Kappeler and Schaik 2002; Schradin et al. 2018). Variation in social organization is obvious between different species.

Typically, only one form of social organization has been described for each species. However, we have long known that many species can have several forms of social organization (Lott 1984, 1991; Maher and Burger 2011; Schradin et al. 2018). While different mechanisms can theoretically lead to intra-specific variation in social organization (Schradin 2013), the most common one is social flexibility (Schradin et al. 2018). Social flexibility is a case of phenotypic plasticity, where individuals of both sexes adapt their social tactic in response to the prevailing environmental conditions, enabling them to switch between different forms of social organization (Schradin et al. 2012). For example, burying beetles (Nicrophorus vespilloides) can form pairs or groups consisting of one male and two females, depending on carrion size (Eggert and Müller 2000; Müller et al. 2006). In house mice (Mus musculus), food availability influences whether they live solitarily, in pairs or in communal groups (Latham and Mason 2004; Berry et al. 2008). Social flexibility can be an adaptation to an environment varying in time but could also be an adaptation to other forms of variation.

In most species, social flexibility occurs due to changes in severity of competition, for example due to changes in population density or resource availability (reviewed by (Maher and Burger 2011; Schradin 2013). Dispersing individuals that migrate into a population where environmental conditions differ from their natal population will benefit if they can adapt their social tactics to prevailing conditions. Thus, social flexibility would be adaptive for dispersing individuals if geographically isolated populations vary in ecological conditions, influencing which social tactic yields the highest fitness. While geographic variation could lead to the 
evolution of social flexibility, this is challenging to study, as multiple populations would have to be monitored simultaneously.

It is well known that different populations of the same species can have different forms of social organisation (Lott 1991; Agnani et al. 2018; Schradin et al. 2018). Multiple studies have compared two populations of one species (reviewed in (Lott 1991; Maher and Burger 2011; Strier 2017). For example, pied kingfishers (Ceryle rudis) form pairs or family groups in areas with a high abundance of high quality nesting sites, but can form polygynous groups in areas where good nesting sites are rare (Reyer 1980, 1984). The comparison of two populations of European badgers (Meles meles) in Spain lead to the hypothesis that differences in population density and landscape structure might influence social organization (Molina-Vacas et al. 2009). Population density has also been hypothesized to explain intraspecific variation between two populations of the mountain brushtail possum (Trichosurus cunninghami) (Martin and Martin 2007) and two populations of the African striped mouse (Rhabdomys pumilio) (Schradin 2005; Schradin and Pillay 2005). A study of four populations of kiwis (Apteryx spp.) differing in population density showed that all populations had pairliving as social organization, although pairs were less stable in the population with the lowest density (Taborsky and Taborsky 1999). Whereas all these studies are interesting, they lack the requisite sample size to show statistically that the observed differences between two (or four) populations are really due to the proposed differences in population density. An early study comparing 23 populations of langurs (Presbytis entrellus) showed that the relationship between population density and group composition is complex and can be revealed only with a sufficiently large number of populations (Moore 1999). Thus, many previous studies comparing two populations discussed the possibility that differences in population density results on variation in social organization, but this was a prediction, not a conclusion, of these studies (Schradin et al. 2010a). To our knowledge, no study has compared a sufficient number of populations (minimum sample size would be 6 populations), for statistical comparisons, as has been propsed by (Maher and Burger 2011).

Intra-specific variation in social organization between populations of the same species could be due to genetic differences caused by local adaptation of isolated populations, or due to social flexibility caused by individuals changing their social tactics when immigrating into a different environment (Schradin 2013). Studying whether social flexibility occurs in a geographically heterogeneous habitat could best be achieved in a small animal species that 
124 has a metapopulation consisting of populations connected by dispersing individuals (also 125 called sub-populations or demes (van Nouhuys 2016)). Our study population of African 126 striped mice (Rhabdomys pumilio) inhabits areas around seasonal riverbeds that are dry for 127 most of the time and carry water for only a few days every couple of years after high rainfall.

128 These populations are separated from each other by dry sandy flats, hills, and mountains, but 129 individuals disperse over these unoccupied areas from population to population (Solmsen et al. 130 2011), forming one large meta-population (van Nouhuys 2016).

132 Striped mice show social flexibility, allowing them to live solitarily or in groups of up to 30 133 adult individuals of both sexes (Schradin et al. 2010a). A correlative field study conducted for 1348 years on one population showed that within this population, social organization depended 135 on reproductive competition and population density (Schradin et al. 2010a). Outside the 136 breeding season, when reproductive competition is absent, striped mice always formed groups 137 independent of population density, but within the breeding season, social organization was 138 density dependent (Schradin et al. 2010a; Schoepf and Schradin 2012). To avoid reproductive 139 competition in the form of female infanticide, females became solitary breeding when 140 territories became available, but remained in communally breeding groups when population 141 density was high (Schradin et al. 2010a; Schoepf and Schradin 2012; Hill et al. 2015). Male 142 social tactics followed females' tactics: more males became solitary roamers when fewer 143 groups of communally breeding females were available to be defended; instead they visited 144 solitary breeding females for mating (Schradin et al. 2010a; Schradin and Lindholm 2011). 145 Thus, temporal variation in population density explained why in this population, many striped 146 mice lived solitarily in some years, while in other years, nearly all lived in groups. The striped 147 mouse offers an ideal system to study whether social flexibility could also be an adaptation to 148 geographic (spatial) variation.

150 Here we tested whether geographic variation in population density is related to social 151 organization in striped mice. Thus, we tested whether the relationship described between population density and the likelihood of group living that was previously described for 8 study years (Schradin et al. 2010a) could be replicated in a one year study of 8 populations.

154 We predicted that more striped mice would be group-living in a population with higher local 155 population density, replicating the relationship between population density and sociality 156 reported previously. In addition, we recorded any individuals dispersing between populations 157 and whether they changed their social tactics, since dispersal could make social flexibility 
adaptive. Social flexibility would allow immigrants to follow the best alternative reproductive tactic depending on the prevailing environmental conditions of the population into which they immigrated.

\section{Methods}

Study area and study period

166 The study was conducted from January to October 2018 in an area covering 5540 ha of the 167 Goegap Nature Reserve in South Africa (S 29 41.56, E 18 1.60). Goegap lies within the semi168 desert biome of the Succulent Karoo, which is characterized by cold and moist winters followed by high food abundance in spring and hot dry summers with low food abundance. The landscape is dominated by short-living ephemerals (in spring) and perennial succulent shrubs. The breeding season of striped mice is in spring (August - November), when population density starts at its minimum.

Data were collected on 8 different sites (Fig. 1). All field sites were located along dry riverbeds with perennial succulent shrubs providing a suitable habitat for striped mice. These included our Main Field Site where we have continuously monitored the striped mouse population since 2001 (Schradin et al. 2012), a field site where an experimental PhD study was done from 2007-2010 (Schoepf and Schradin 2012) (Klein Goegap) and 6 field sites where striped mice had been trapped for a population genetics study in 2008, and which found dispersal among these populations (Solmsen et al. 2011). Thus, these populations form one metapopulation that could be viewed as 8 sub-populations or 8 demes. We retain the term

182 "population" for each site, as there was no direct contact between them, and all were isolated 183 from each other by habitat not inhabited by striped mice (Fig. 1).

186 Each population was trapped 4 times. Trapping during January (onset of the dry season, no breeding), April (middle of the dry season, no breeding) and July (end of dry season, no breeding) was done to ensure we have viable populations for our study during the breeding season and to monitor potential dispersal between populations. The Gate population became locally extinct in July and the Highlands population by September, leaving us with 6

191 populations in spring for study (Fig. 1). Extinction might have been associated with the very 
192 dry conditions of the years 2015 to 2018, which experienced less rain than the average of

$193151 \mathrm{~mm} /$ year since 2005 (2015: 65mm; 2016: 85mm; 2017: 41 mm; 2018: 71mm).

194

195 Data collection regarding social organization was done during the breeding season

196 (September and October). Before trapping, field sites were pre-baited for two days by casting

197 bait around trapping stations. In January, trapping was done for 3 days at 6 sites but for 5 days

198 at the field sites with lower trap success, i.e. Gate and Office. During all subsequent trapping

199 periods, all field sites were trapped for 5 days.

200

201 At each population, we trapped along transects of $580 \mathrm{~m}$ consisting of 30 trapping stations,

202 one every $20 \mathrm{~m}$ under shrubs providing sufficient shelter or where signs of striped mice 203 activity were apparent (feces, tracks). Two traps were set at each trapping station (60 traps in 204 total for each field site). In the morning, we set traps $20 \mathrm{~min}$ before sunlight was incident on 205 the field site because activity of striped mice is dependent on the onset of direct sunlight 206 (Schradin et al. 2007). Traps were checked twice, first 30min after the sun started shining on 207 the first stations and again approx. 40min later. Traps were then unset (locked open) for the 208 hot period of the day. In the evening, we set traps $45 \mathrm{~min}$ before sundown and checked traps 209 once after the sunlight was no longer incident on the field site. Striped mice never spent more 210 than one hour in traps. Trapped striped mice were weighed, sexed, and permanently marked 211 with ear tags (National Band and Tag Co., USA) (Schradin and Pillay 2004; Schradin 2006).

212 Striped mice were also temporarily marked with hair dye (Inecto Rapido, Pinetown, South 213 Africa) only during the breeding season in September / October to allow for individual 214 identification during direct observations at their sleeping sites (Schradin and Pillay 2004).

217 Determination of social tactic

218 It was not possible to record data blind because our study involved focal animals in the field.

219 The social tactic was determined during the breeding season in September/ October to 220 establish whether individuals were living solitarily or in groups. For this, each trapped 221 individual weighing $\geq 30 \mathrm{~g}$ received a radio-transmitter (MD-2C transmitters from Holohil, 222 Canada) weighing 2.0 to 3.5g. We radio-tracked striped mice using an AOR 8000 wide-range 223 receiver once during their activity period in the afternoon before trapping and a second time at 224 night to determine sleeping sites. 
226 Radio-tracking started on the same day the radio-collar was fitted. The sleeping site was

227 determined at night and we also placed 4 to 6 traps at the nesting site and started trapping 228 there the next morning for the rest of the study. Any additional striped mice trapped were 229 marked and received a radio-collar; trapping at nesting sites continued, with more traps being 230 set if necessary. Some sleeping sites were also observed during mornings and afternoons to 231 determine whether striped mice not carrying transmitters were present. We prioritized 232 sleeping sites where only one mouse was radio-tracked (assumed to be solitary) over sleeping 233 sites were several mice were radio-tracked (known to be group living) to verify that an 234 individual was solitary. If after the original five days of trapping, the social organization was 235 not apparent for every individual, radio-tracking, trapping and observations continued for up 236 to another seven days. We did not have to spend any extra days at the Main Field Site, since 237 we knew the social tactics of all trapped mice there, nor on the two field sites where no striped 238 mice were trapped within 5 days (regarded as extinct: Gate and Highland). In total we spent 6 239 days at Office, 10 days at Tourist Road, 11 days at Riverbed End and Klein Goegap, and 12 240 days at Mountains. We determined group- versus solitary living by using the following 241 definitions from our previous studies (Schradin et al. 2009; Schradin and Yuen 2011). 1. 242 Group-living: two or more adult mice sleep together in the same nest for a minimum of three 243 consecutive nights. Groups consisted either only of adult females, a pair, or adults of both 244 sexes. 2. Solitary living female (with or without pups): a female sleeps alone for a minimum 245 of three consecutive nights and we either trapped no other adult individual at the same nest(s) 246 for at least three days, or other adult individuals trapped there were radio-tracked at night at 247 another nest. 3. Solitary living male (roamer): a male sleeps alone for a minimum of three 248 consecutive nights and we either trapped no other adult individual at the same nest(s) for at 249 least three days, or other adult individuals trapped there were radio-tracked at night at another 250 nest. Altogether we determined the social tactics of 39 males and 48 females (sex ratio: 0.81 ).

252 Population density

253 Population density was estimated for the breeding season only. The habitat in Goegap is 254 heterogenous and many areas are not inhabited by striped mice, as they do not provide the 255 necessary resources, such as food and shelter (Schradin and Pillay 2006; Solmsen et al. 2011). 256 While we chose our trapping transects in areas suitable for striped mice, the long transects 257 often also included unoccupied areas, especially sandy areas without vegetation providing 258 food and cover. To calculate population density as an indicator of competition for scarce 259 resources, we thus only included the areas used by striped mice. For this, we used the GPS 
points of all sleeping sites, all trapping sites where striped mice were trapped, and of all radio-

261 tracking data collected during afternoons. Using the minimum polygon method, we then 262 determined the size of the area in hectares using the software QGIS 3.6. For individual home ranges of striped mice, convex polygons correlated highly and significantly with Kernel estimates (Schradin and Pillay 2006; Schradin et al. 2010b), but as Kernel contours would be more affected by single individuals with small home ranges, we used convex polygons. Visual inspection of the polygons did not indicate any outliers having a huge impact on field site estimate.For each population, population density was then calculated as the number of adult striped mice (body mass $\geq 30 \mathrm{~g}$ ) per hectare.

Statistical analyses

271

Data were analyzed using $\mathrm{R}$ v. 3.6.1 (The $\mathrm{R}$ foundation for statistical computing, http://www.r-project.org/), GraphPad InStat 3.05 and CurveExpert 1.4. Data are reported as means \pm standard deviation. Because we had data from only 6 populations, restricting the statistical power of our analysis, we could not include co-variates into the statistical analysis and we thus focused on population density, the variable of interest in our study. However, we measured food availability, rainfall and the percentage of cover and report that they had no influence on sociality with the given sample size (see electronic supplement). Population density was $\log$ transformed for statistical analysis since the relationship with sociality was

\section{Results}

Due to extremely dry conditions during the years 2015-2018, population density was generally low, and two populations had become extinct by the onset of the study. For the remaining 6 populations, population density ranged from 1.1 striped mice/ha to $22.4 \mathrm{mice} / \mathrm{ha}$, with a mean of $5.1 \pm 8.5$ (SD) mice/ha (Fig. 2). In one population (Riverbed End), no striped 289

There was a significant regression between the percentage of striped mice living in groups and $\log$ transformed population density $\left(\mathrm{r}^{2}=0.821, \mathrm{p}=0.01\right.$; Fig. $\left.2 \mathrm{~A}\right)$. At lower population

292 density in a population, more striped mice lived solitarily. For females alone, the regression 293 was also significant $\left(r^{2}=0.73, p=0.03\right)$, and also for males $\left(r^{2}=0.91, p=0.004\right)$. Significantly 
more females $(66.5 \pm 36.8 \%)$ than males $(50.0 \pm 33.9 \%)$ lived in groups (paired $t_{5}=2.75$, $295 \mathrm{p}=0.04)$.

297 Using CurveExpert, the relationship was best described by a non-linear regression with the 298 formula $y=98.89 *(1-(\exp (-0.516 x)))$, with y representing the percentage of group-living 299 striped mice in the population, and $x$ the population density in striped mice/ha (Fig. 2B). The 300 correlation coefficient was $0.942(\mathrm{SE}=14.74)$ indicating very high model fit. For females and males alone, the best fit curves were very similar (females: $y=97.77 *(1-(\exp (-0.76 x)))$,

$302 \mathrm{SE}=15.91$, correlation coefficient $=0.938 ;$ males: $\mathrm{y}=97.87 *(1-(\exp (-0.34 \mathrm{x}))), \quad \mathrm{SE}=11.14$, 303 correlation coefficient $=0.960$ ). In comparison, the best fit model from the data published in 3042010 was $y=91.3-(136 / x)$, the correlation coefficient was $0.984(\mathrm{SE}=5.82)$ (Schradin et al. 2010a); inserted in Fig. 2B for comparison). Our small sample size did not allow us to include additional environmental co-factors into the analysis; in any case, from the start of the project planning, we focused on the effect of population density as main effect. In the electronic supplement we show that all regressions between the dependent variable (\% group-living striped mice) and several environmental co-factors (number of food plants, plant cover and rainfall) were non-significant, indicating that population density, the a priori chosen main factor, was the most important.

313 During the entire study, we observed seven individuals (five males and two females) 314 originating from Main Field Site that immigrated into three other populations (Table 1). Of 315 those, three dispersal events occurred during the breeding season (last trapped on main field 316 site after $1^{\text {st }}$ of July and trapped on new field site in September; Table 1). For three males that 317 dispersed during the breeding season, we established that they had changed their social tactic 318 from group-living philopatric male at Main Field Site to solitary living roamer at the new 319 population (Table 1).

\section{Discussion}

324 Social flexibility has been interpreted as an adaptation to changing environments. Change 325 occurs not only in time but also in space. Here we showed for the first time that geographic 326 variation in population density is significantly related to social flexibility, a prediction that 327 emerged from many field studies on multiple species where differences between two 
populations were observed (Schradin and Pillay 2005; Martin and Martin 2007; Molina-Vacas et al. 2009). We showed that 6 populations of a larger meta-population differed in their degree of sociality, depending on population density. Thus, within this metapopulation, individuals being able to switch from group- to solitary living and back might benefit from this flexibility not only when the environment changes over time (Schradin et al. 2010a), but also when they disperse into another environment.

Dispersal is adaptive when there is a chance that a dispersing individual ends up in an environment which differs sufficiently from its original environment to generate higher fitness. A previous study using molecular markers showed that striped mice disperse several kilometers over unoccupied habitats between populations (Solmsen et al. 2011). When populations of the same species differ in social organization, this can either be due to them being isolated and having evolved different social tactics fixed between populations, or due to social flexibility of individuals (Schradin 2013). Genetic studies (Solmsen et al. 2011) and our

342 limited observations indicate that dispersal between populations occurs and that dispersing striped mice changed their social tactics, indicating that population differences in social organization are due to social flexibility rather than genetic differentiation. We found dispersal throughout the year, with most events in July, which corresponds to previous findings of the same population using a large sample size (Vuarin et al. 2019). While more exhaustive studies are needed to understand the fitness consequences of dispersal, here we demonstrate dispersal of individuals over several kilometers between populations that differed in population density and social organization and associated reproductive tactic change in some dispersers.

Striped mice are well known for their social flexibility, i.e. individuals being able to switch 353 from group- to solitary living and back to group-living (Schradin et al. 2012). This has been 354 demonstrated first with long-term data collected during 8 years from our field site, where 355 more striped mice were group-living at a higher population density (Schradin et al. 2010a), in 356 agreement with the habitat saturation hypothesis (Koenig and Pitelka 1981; Emlen 1982; Komdeur 1992). Female tactics drive male sociality, since for males it is beneficial to join groups of communally breeding females and defend them as the only breeding male against other males. However, when many females live solitarily, solitary living males visiting several single females can also have high reproductive success (Schradin and Lindholm 2011). Importantly, single breeding females have much larger home ranges than communal groups, 
362 making it impossible for single males to defend the home ranges of multiple solitary females

363 (Schradin et al. 2010b). Reproductive competition between males is high, and single males

364 defending groups of communally breeding females can explain why we found more solitary

365 males than females in every population. Our current study extends our previous findings,

366 demonstrating that striped mice of different populations can either live solitarily (one

367 population), in groups (one population) or that within an area both solitary and group-living

368 can occur (4 populations). Thus, social flexibility is a key characteristic of striped mice both

369 in time and space.

370

371 Here we showed that 6 populations of a meta-population of striped mice differed both in

372 population density and sociality. The relationship between population density and sociality

373 causing intra-specific variation in social organization has been hypothesized by comparing

374 two populations in several different species (e.g. brushtail possums (Martin and Martin 2007),

375 Europeans badgers (Molina-Vacas et al. 2009), including striped mice (Schradin and Pillay

376 2005). However, comparing only two populations $(\mathrm{N}=2)$ reduces statistical validity. Thus,

377 such studies are useful to make predictions, but not to draw conclusions, and it has been

378 suggested that more populations need to be studied in the future (Maher and Burger 2011).

379 We found within the metapopulation studied that the lower the population density, the more

380 likely striped mice were solitary. Our six populations were studied within 1.5 months in the

381 same nature reserve and under similar ecological conditions (electronic supplement 1). The

382 relationship was not linear, indicating that solitary living is favored at very low population

383 density, but then group-living becomes more quickly common and reaches a plateau at which

384 nearly all striped mice are living in groups (Fig. 2). Our study indicates that some female

385 striped mice prefer to breed solitarily when free territories are available, and that more males

386 follow a solitary roaming tactic when more solitary females can be visited. Female striped

387 mice in communal groups suffer from reproductive competition in the form of female-female

388 aggression and female infanticide (Schradin et al. 2010a). In this context, solitary living is a

389 beneficial alternative tactic (Hill et al. 2015). Social flexibility thus allows striped mice to

390 respond to prevailing conditions. These studies help us to understand the reasons for animals

391 living solitarily, a point often missed in behavioral research that normally focuses on the

392 contrary point of why animals live in groups (Krause and Ruxton 2002; Hill et al. 2015;

393 Kappeler 2019).

394 
395 Experimental manipulation of population density has resulted in changes in social

396 organisation in the cichlid Neolamprologus pulcher in captivity (Bergmüller et al. 2005),

397 prairie voles (Microtus ochrogaster) kept in enclosures (Lucia et al. 2008), and free-living

398 populations of striped mice (Schoepf and Schradin 2012) and Seychelles warblers

399 (Acrocephalus sechellensis) (Komdeur 1992, 1994). Whereas these studies focussed on one

400 population, a multitude of previous studies comparing two populations showed that intra-

401 specific variation in social organisation between populations is widespread (Taborsky and

402 Taborsky 1999; Martin and Martin 2007; Molina-Vacas et al. 2009) and can be related to

403 population density (Schradin 2013), for example in prairie voles (Streatfeild et al. 2011).

404 Variation in social organisation between two populations has typically been discussed to be

405 adaptive, but these studies lacked statistical power to test this assumption, creating hypotheses

406 but not reaching conclusions. In caviomorph rodents, intra-specific variation in social systems

407 is common and apparently related to ecological factors (but in degus, at least, it is not related

408 to population density (Ebensperger et al. 2011)). However, most studies on caviomorphs were

409 purely observational, suffering from low sample size and short study periods, such that

410 conclusions could not be drawn with confidence, again leading to predictions rather than

411 conclusions (Maher and Burger 2011). Maher and Burger (2011) recommended for the future

412 to compare several populations of the same species, which is what we have done here. Thus,

413 multiple previous studies suggested that IVSO between populations is related to population

414 density, and here we showed this for the first time statistically.

415

416 In many primate species, individual flexibility in social behavior stabilises the social

417 organisation, for example by changing dominance hierarchies and coalitions, such that the

418 main form of social organisation can be maintained (Schradin et al. 2018). In comparison,

419 some other species, such as striped mice, cannot respond to conflict by adjusting their social

420 hierarchy and groups might instead break up, leading to intra-specific variation in social

421 organisation (Schradin et al. 2018). Nevertheless, variation in social organisation is also

422 common in primates (Strier 2017; Agnani et al. 2018) and explained by socio-ecological

423 models focussing on resource abundance (Dunbar 1988; Kappeler and Schaik 2002; Kappeler

424 et al. 2013, 2017; Koenig et al. 2013) and demography (Moore 1999; Strier 2017). Comparing

425 multiple populations of the same species helped to understand the adaptive significance of

426 infanticide in langurs independent of population density (Moore 1999). For primates, it has

427 been suggested that intra-specific variation must be taken into account in comparative studies

428 (Sandel et al. 2016) because it significantly changes our understanding of primate social 
evolution (Kappeler and Fichtel 2016). Similar claims have been made in the studies regarding cooperative breeding in birds, where the importance of variation within species has been ignored (Griesser and Suzuki 2016).

432

433 Individuals of both sexes changing their social tactics (individual trait) can change the social 434 system of an entire population, which is called social flexibility (observed at the population 435 level; (Schradin et al. 2012). It has been hypothesized that the variation in social organization 436 observed between two populations of a species might be due to differences in population 437 density (Taborsky and Taborsky 1999; Schradin and Pillay 2005; Martin and Martin 2007; 438 Molina-Vacas et al. 2009) but more populations must be studied simultaneously to test this 439 hypothesis (Maher and Burger 2011). To date, this phenomenon had been studied in relation 440 to environmental change over time in one population (Schradin et al. 2018, 2019). Here we 441 showed that, for the meta-population studied, intra-specific variation in social organization 442 can be related to geographic variation in population density. Thus, social organization can 443 differ at different localities simultaneously in time depending on population density. How 444 individual dispersal tactics and associated changes in social tactics benefit individual fitness 445 will require further studies. Our study emphasizes the importance of considering intra-specific 446 variation in social tactics in both a spatial and temporal context.

\section{Compliance with Ethical Standards}

$450 \quad$ Funding

451 This work was supported by the National Research Foundation (South Africa), the University 452 of Witwatersrand (South Africa), and the CNRS (France) under the framework of the 453 International Research Project DROUGHT (Response to Drought, Climate Change and 454 Climate Unpredictability: Social Flexibility, Adaptation, and Species Range Shifts)455 Laboratoire International Associé (IRP / LIA).

Conflict of Interest

We declare that we have no conflict of interest. 
All animal experimentation met the ABS/ASAB guidelines for ethical treatment of animals.

462 Animal ethics clearance was provided by the University of the Witwatersrand (AESC

463 2007/40/01), following the guidelines for the use and care of animals in teaching and research

464 of the University of the Witwatersrand which complies with the University's ethical and legal

465 practices and with the National Code.

Data availability

468 All data generated or analysed during this study are included in the supplementary

469 information files of this published article.

\section{References}

472

473

Agnani P, Kauffmann C, Hayes LD, Schradin C (2018) Intra - specific variation in social organization of Strepsirrhines. Am J Primatol 80:e22758

Bergmüller R, Heg D, Taborsky M (2005) Helpers in a cooperatively breeding cichlid stay and pay or disperse and breed, depending on ecological constraints. Proc R Soc Lond B 272:325-331

Berry RJ, Tattersall FH, Hurst J (2008) Genus Mus. In: Harris S, Yalden DW (eds) Mammals of the British Isles Handbook, 4th edn. The Mammal Society, Southampton, UK, pp 141-149

Dunbar RIM (1988) Socio-ecological systems. In: Dunbar RIM (ed) Primate Social Systems. Cornell University Press, New York, pp 262-291

Eggert A-K, Müller JK (2000) Timing of oviposition and reproductive skew in cobreeding female burying beetles (Nicrophorus vespilloides). Behav Ecol 11:357-366

Emlen ST (1982) The evolution of helping. I. An ecological constraints model. Am Nat 119:29-39

Griesser M, Suzuki TN (2016) Occasional cooperative breeding in birds and the robustness of comparative analyses concerning the evolution of cooperative breeding. Zool Lett 2:7

Hill DL, Pillay N, Schradin C (2015) Alternative reproductive tactics in female striped mice: heavier females are more likely to breed solitarily than communally. J Anim Ecol 84:1497-1508

Kappeler PM (2019) A framework for studying social complexity. Behav Ecol Sociobiol $73: 13$

Kappeler PM, Barrett L, Blumstein DT, Clutton-Brock TH (2013) Constraints and flexibility in mammalian social behaviour: introduction and synthesis. Phil Trans R Soc B 368:20120337

Kappeler PM, Clutton-Brock T, Shultz S, Lukas D (2019) Social complexity: patterns, processes, and evolution. Behav Ecol Sociobiol 73:5

Kappeler PM, Cuozzo FP, Fichtel C et al (2017) Long-term field studies of lemurs, lorises, and tarsiers. J Mammal 98:661-669

Kappeler PM, Fichtel C (2016) The evolution of eulemur social organization. Int J Primatol 37:10-28

Kappeler PM, Schaik CPv (2002) Evolution of primate social systems. Int J Primatol 23:707740 
Koenig A, Scarry CJ, Wheeler BC, Borries C (2013) Variation in grouping patterns, mating systems and social structure: what socio-ecological models attempt to explain. Phil Trans R Soc B 368:20120348

Koenig WD, Pitelka FA (1981) Ecolgical factors and kin selection in the evolution of cooperative breeding in birds. In: Alexander RD, Tinkle DW (eds) Natural Selection and Social Behavior: Recent Research and New Theory. Chrion Press, New York, pp 261-280

Komdeur J (1992) Importance of habitat saturation and territory quality for evolution of cooperative breeding in the Seychelles warbler. Nature 358:493-495

Komdeur J (1994) Experimental evidence for helping and hindering by previous offspring in the cooperative-breeding Seychelles warbler Acrocephalus sechellensis. Behav Ecol Sociobiol 34:175-186

Krause J, Ruxton GD (2002) Living in Groups. Oxford University Press, Oxford

Latham N, Mason G (2004) From house mouse to mouse house: the behavioural biology of free-living Mus musculus and its implications in the laboratory. Appl Anim Behav Sci $86: 261-289$

Lott DF (1984) Intraspecific variation in the social systems of wild vertebrates. Behaviour 88:266-325

Lott DF (1991) Intraspecific Variation in the Social Systems of Wild Vertebrates. Cambridge University Press, New York

Lucia KE, Keane B, Hayes LD, Lin YK, Schaefer RL, Solomon NG (2008) Philopatry in prairie voles: an evaluation of the habitat saturation hypothesis. Behav Ecol 19:774783

Maher CR, Burger JR (2011) Intraspecific variation in space use, group size, and mating systems of caviomorph rodents. J Mammal 92:54-64

Martin JK, Martin AA (2007) Resource distribution influences mating system in the bobuck (Trichosurus cunninghami: Marsupialia). Oecologia 154:227-236

Molina-Vacas G, Bonet-Arboli V, Rafart-Plaza E, Rodriguez-Teijeiro JD (2009) Spatial ecology of European badgers (Meles meles) in mediterranean habitats of the northeastern Iberian peninsula. I: Home range size, spatial distribution and social organisation. Vie Milieu 59:223-232

Moore J (1999). Population density, social pathology, and behavioral ecology. Primates 40:122

Müller JF, Braunisch V, Hwang W, Eggert A-K (2006) Alternative tactics and individual reproductive success in natural associations of the burying beetle, Nicrophorus vespilloides. Behav Ecol 18:196-203

Reyer H-U (1980) Flexible helper structure as an ecological adaptation in the pied kingfisher (Ceryle rudis rudis L.). Behav Ecol Sociobiol 6:219-227

Reyer H-U (1984) Investment and relatedness: a cost/benefit analysis of breeding and helping in the pied kingfisher (Ceryle rudis). Anim Behav 32:1163-1178

Sandel AA, Miller JA, Mitani JC, Nunn CL, Patterson SK, Garamszegi LZ (2016) Assessing sources of error in comparative analyses of primate behavior: Intraspecific variation in group size and the social brain hypothesis. J Hum Evol 94:126-133

Schoepf I, Schradin C (2012) Better off alone! Reproductive competition and ecological constraints determine sociality in the African striped mouse (Rhabdomys pumilio). $\mathrm{J}$ Anim Ecol 81:649-656

Schradin C (2005) When to live alone and when to live in groups: ecological determinants of sociality in the African striped mouse (Rhabdomys pumilio, Sparrman, 1784). Belg J Zool 135 (suppl):77-82

Schradin C (2006) Whole day follows of the striped mouse. J Ethol 24:37-43 
Schradin C (2013) Intraspecific variation in social organization by genetic variation, developmental plasticity, social flexibility or entirely extrinsic factors. Phil Trans R Soc B 368:20120346

Schradin C, Hayes LD, Pillay N, Bertelsmeier C (2018) The evolution of intraspecific variation in social organization. Ethology 124:527-536

Schradin C, König B, Pillay N (2010a) Reproductive competition favours solitary living while ecological constraints impose group-living in African striped mice. J Anim Ecol 79:515-521

Schradin C, Krackow S, Schubert M, Keller C, Schradin B, Pillay N (2007) Regulation of activity in desert-living striped mice: The importance of basking. Ethology 113:606614

Schradin C, Lindholm AK (2011) Relative fitness of alternative male reproductive tactics in a mammal varies between years. J Anim Ecol 80:908-917

Schradin C, Lindholm AK, Johannesen J, Schoepf I, Yuen C-H, König B, Pillay N (2012) Social flexibility and social evolution in mammals: a case study of the African striped mouse (Rhabdomys pumilio). Mol Ecol 21:541-553

Schradin C, Pillay N (2004) The striped mouse (Rhabdomys pumilio) from the succulent karoo of South Africa: A territorial group living solitary forager with communal breeding and helpers at the nest. J Comp Psychol 118:37-47

Schradin C, Pillay N (2005) Intraspecific variation in the spatial and social organization of the African striped mouse. J Mammal 86:99-107

Schradin C, Pillay N (2006) Female striped mice (Rhabdomys pumilio) change their home ranges in response to seasonal variation in food availability. Behav Ecol 17:452-458

Schradin C, Pillay N, Bertelsmeier C (2019) Social flexibility and environmental unpredictability in African striped mice. Behav Ecol Sociobiol 73:94

Schradin C, Scantlebury M, Pillay N, König B (2009) Testosterone levels in dominant sociable males are lower than in solitary roamers: physiological differences between three male reproductive tactics in a sociably flexible mammal. Am Nat 173:376-388

Schradin C, Schmohl G, Rödel HG, Schoepf I, Treffler SM, Brenner J, Bleeker M, Schubert M, König B, Pillay N (2010b) Female home range size is regulated by resource distribution and intraspecific competition: a long-term field study. Anim Behav 79:195-203

Schradin C, Yuen C-H (2011) Hormone levels of male African striped mice change as they switch between alternative reproductive tactics. Horm Behav 60:676-680

Solmsen N, Johannesen J, Schradin C (2011) Highly asymmetric fine-scale genetic structure between sexes of African striped mice and indication for condition dependent alternative male dispersal tactics. Mol Ecol 20:1624-1634

Streatfeild CA, Mabry KE, Keane B, Crist TO, Solomon NG (2011) Intraspecific variability in the social and genetic mating systems of prairie voles, Microtus ochrogaster. Anim Behav 82:1387-1398

Strier KB (2017) What does variation in primate behavior mean? Am J Phys Anthropol $162: 4-14$

Taborsky B, Taborsky M (1999) The mating system and stability of pairs in kiwi Apteryx spp. J Avian Biol 30:143-151

van Nouhuys S (2016) Metapopulation Ecology. In: Encyclopedia of Life Sciences (eLS). John Wiley \& Sons Ltd, Chichester, pp 1-9

Vuarin P, Pillay N, Schradin C (2019) Elevated basal corticosterone levels increase disappearance risk of light but not heavy individuals in a long-term monitored rodent population. Horm Behav 113:95-102 
Table 1

607 Individual striped mice that dispersed from Main Field site to a different population

\begin{tabular}{|c|c|c|c|c|c|c|}
\hline Sex & $\begin{array}{l}\text { Last trapped on } \\
\text { main field site }\end{array}$ & $\begin{array}{l}\text { New } \\
\text { population }\end{array}$ & $\begin{array}{l}\text { First trapped } \\
\text { at new } \\
\text { population }\end{array}$ & $\begin{array}{l}\text { Last trapped } \\
\text { at new } \\
\text { population }\end{array}$ & $\begin{array}{l}\text { Social tactic at } \\
\text { main field site }\end{array}$ & $\begin{array}{l}\text { Social tactic at } \\
\text { new population }\end{array}$ \\
\hline Male & 27.03.2018 & $\begin{array}{l}\text { Klein } \\
\text { Goegap }\end{array}$ & 25.04 .2018 & 25.04 .2018 & Group-living & $\begin{array}{lr}\text { Tactics not } \\
\text { determined in } \\
\text { April }\end{array}$ \\
\hline Female & 11.04 .2018 & $\begin{array}{l}\text { Klein } \\
\text { Goegap }\end{array}$ & 27.04 .2018 & 27.04 .2018 & Group-living & $\begin{array}{lr}\text { Tactics not } \\
\text { determined in } \\
\text { April }\end{array}$ \\
\hline Male & 09.06 .2018 & Mountain & 18.07 .2018 & 10.09 .2018 & Group-living & Solitary living \\
\hline Male & 02.02 .2018 & $\begin{array}{l}\text { Riverbed } \\
\text { End }\end{array}$ & 07.09 .2018 & 13.09 .2018 & Group-living & Solitary living \\
\hline Female & 18.07 .2018 & $\begin{array}{l}\text { Riverbed } \\
\text { End }\end{array}$ & 14.09 .2018 & 14.09 .2018 & Group-living & $\begin{array}{l}\text { Not determined } \\
\text { because it were } \\
\text { trapped on last } \\
\text { day }\end{array}$ \\
\hline Male & 27.07.2018 & $\begin{array}{l}\text { Klein } \\
\text { Goegap }\end{array}$ & 24.09 .2018 & 03.10 .2018 & Group-living & Solitary living \\
\hline Male & 08.09 .2018 & $\begin{array}{l}\text { Klein } \\
\text { Goegap }\end{array}$ & 05.10 .2018 & 05.10 .2018 & $\begin{array}{l}\text { Floater? (Only } \\
\text { trapped once) }\end{array}$ & $\begin{array}{l}\text { Floater? (Only } \\
\text { trapped once at } \\
\text { each site) }\end{array}$ \\
\hline
\end{tabular}

608

609 


\section{$610 \quad$ Figure captions}

611

612 Fig. 1 Schematic representation of the 8 populations studied in Goegap Nature Reserve, South 613 Africa. Dashed lines represent roads and tracks, which are often along dry riverbeds. All

614 populations were separated by areas not inhabited by striped mice such as sandy flats or 615 mountain passes. While striped mice were trapped at all localities in April, the Gate 616 population had become locally extinct by July and the Highlands population by September 617

618 Fig. 2 A) Relationship between log population density and the percentage of striped mice

619 living in groups. B) Raw data. Black: data from 6 populations studied simultaneously in 2018

620 at 6 distinct geographic locations. Grey: published data from 8 different years in the

621 population Main Field Site (Schradin et al. 2010a), which provided the predictions for the

622 current study. Best fit curves on the raw data were fitted using CurveExpert

623

624 


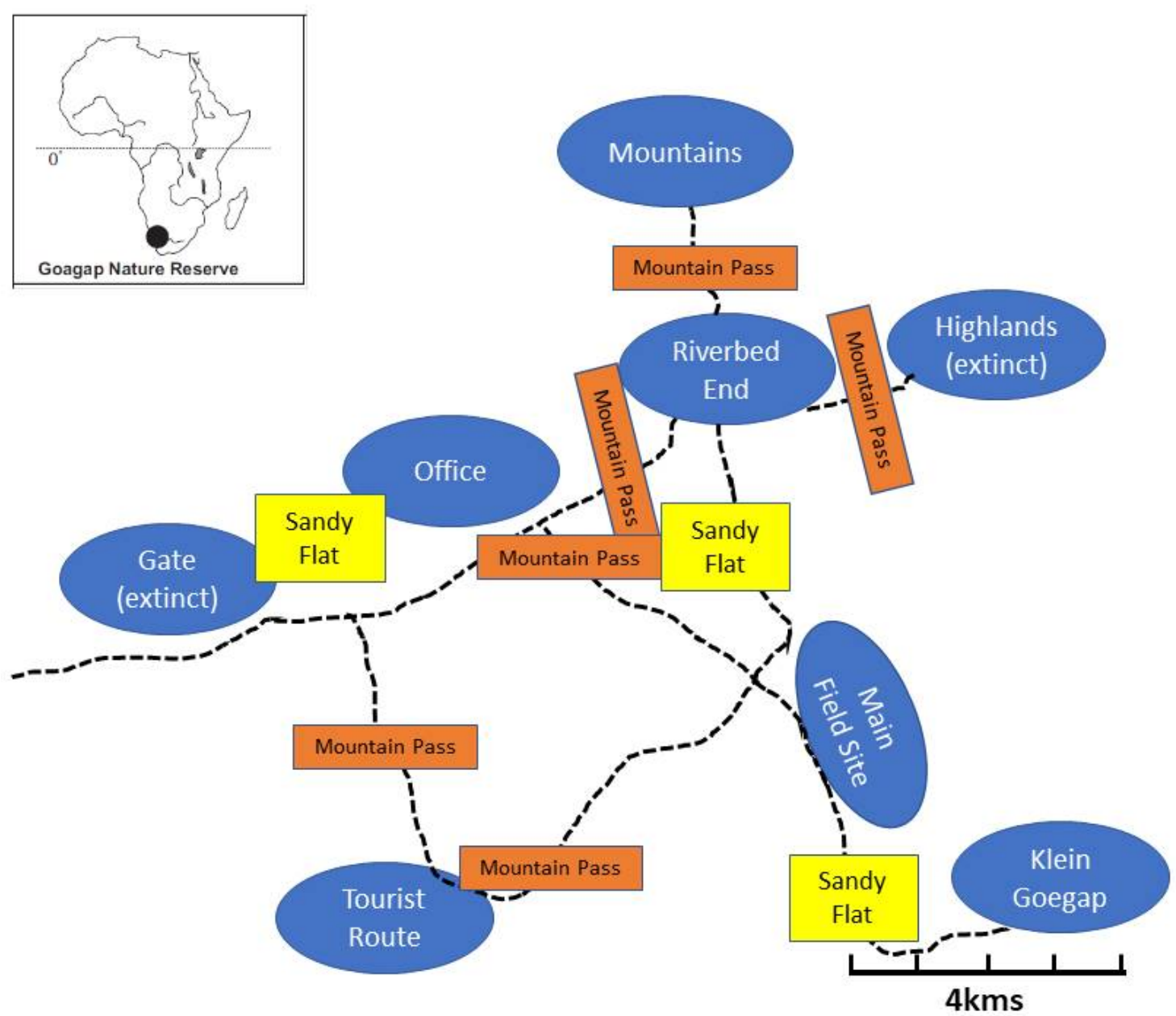

625

626 Figure 1

627 
628

629

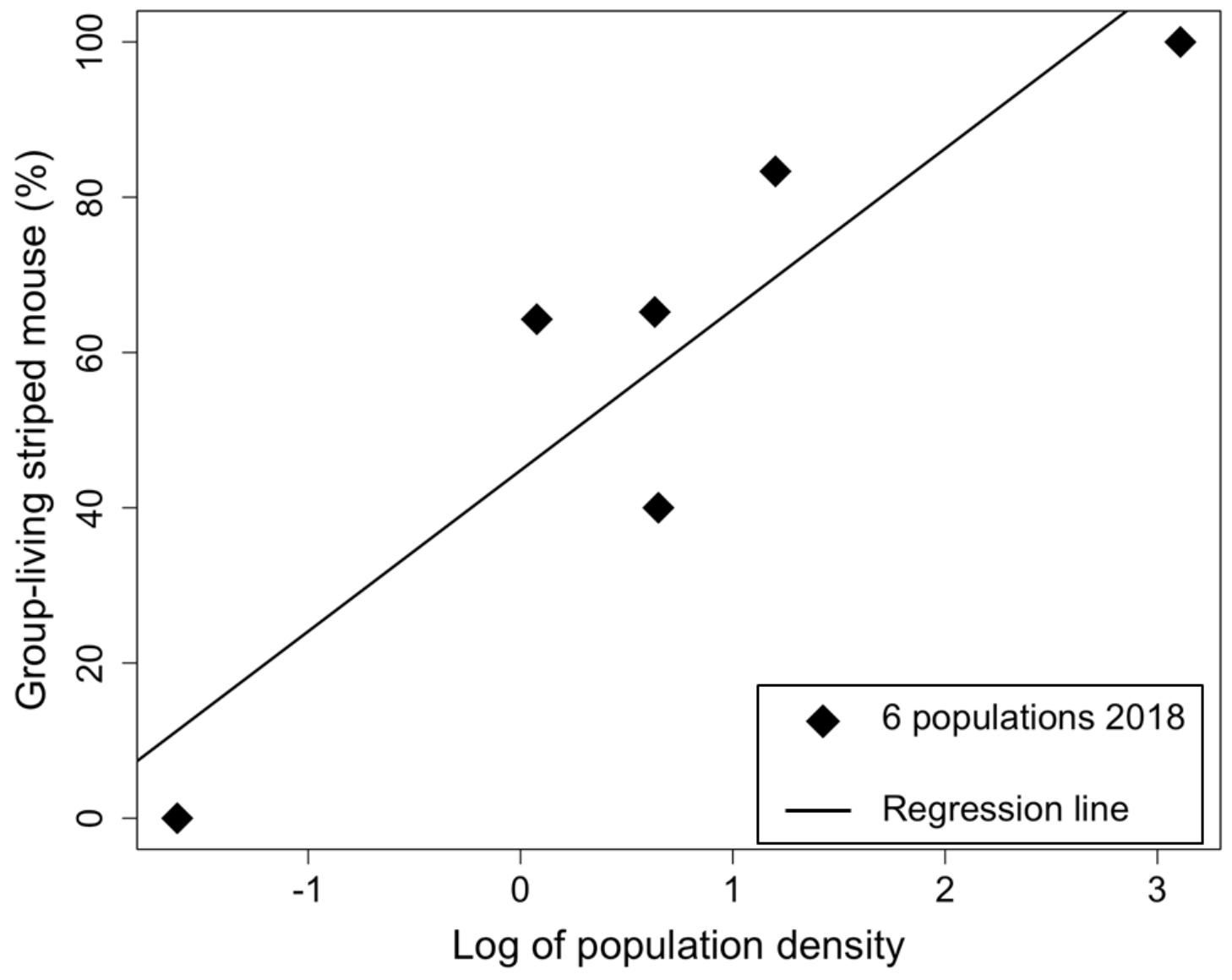

630

631

632 Figure 2 A

633

634 


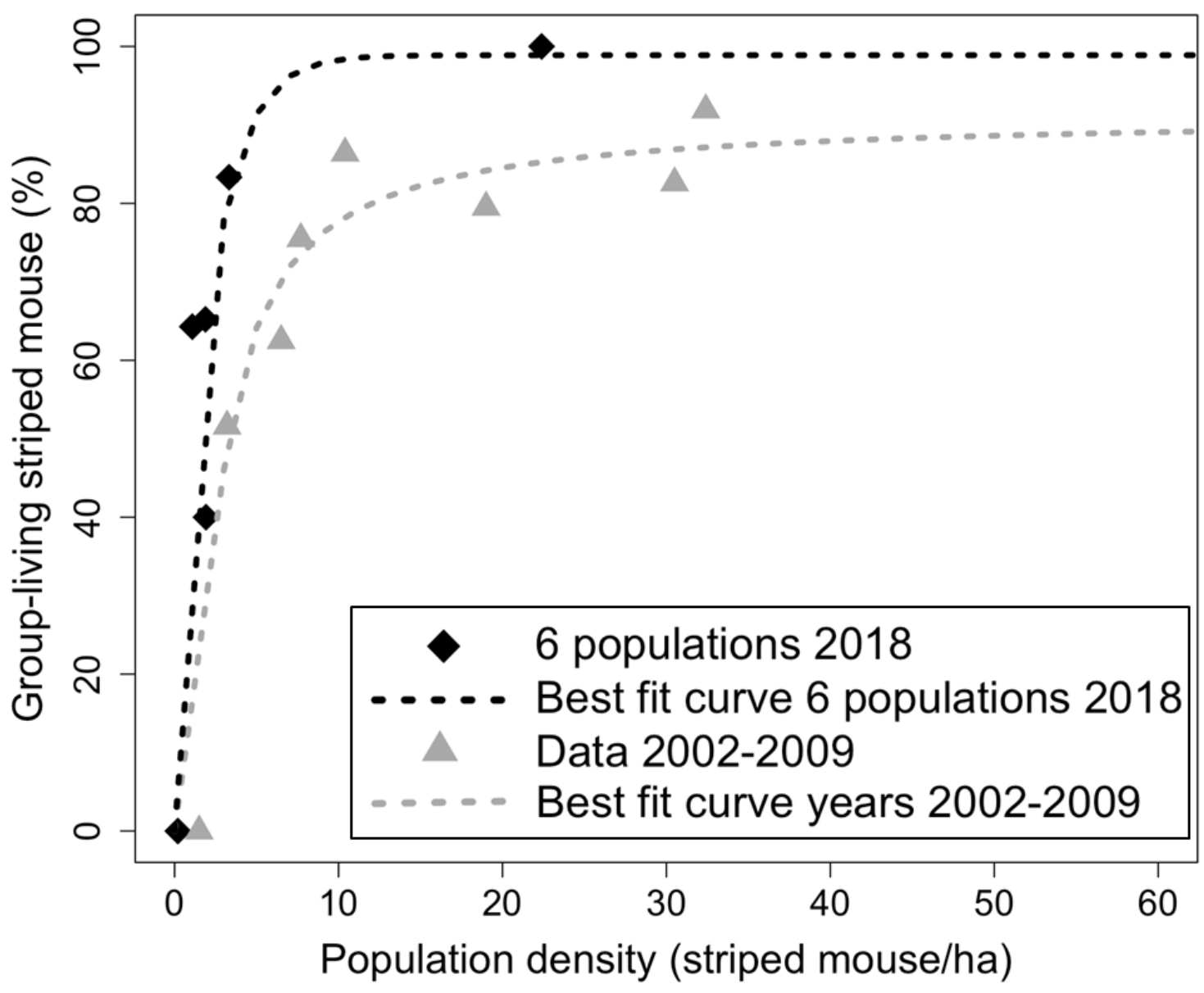

635

Figure 2 B

637 